\title{
Teacher Canditates' Environmental Awareness and Environmental Sensitivity
}

\author{
Emine Zehra Turan ${ }^{1}$ \\ ${ }^{1}$ Assistant Professor, Faculty of Theology, Nevsehir Haci Bektas Veli University, Nevsehir, Turkey \\ Correspondence: Emine Zehra TURAN, Faculty of Theology, Nevsehir Haci Bektas Veli University, 2000 Evler \\ Mah., Zübeyde Hanim Cad., 50300, Nevsehir, Turkey. E-mail: ezehraturan@ hotmail.com
}

Received: July 8, 2019

Accepted: July 25, 2019

Online Published: July 26, 2019

doi:10.5430/ijhe.v8n4p202

URL: https://doi.org/10.5430/ijhe.v8n4p202

\begin{abstract}
Teachers have a huge effect on raising students' environmental awareness and helping them develop sensitivity to environmental issues. The aim of this study was to examine the environmental awareness and environmental sensitivity of teacher candidates. In the study, "Environmental Awareness and Environmental Sensitivity " scale developed by Timur and Yilmaz (2003) for teacher candidates (277) was used as data collection tool. Descriptive analysis method was used for data analysis by SPSS program. As a result of the study, it was determined that there was no significant difference between the branches and the genders of Environmental Awareness and Environmental Sensitivities of candidates teachers. A significant difference was found between the branches in the Environmental Sensitivity dimension of the scale. Teacher candidates' Environmental Awareness and Environmental Sensitivity do not change according to their gender. It was found that Religious Culture and Ethics Teaching teacher candidates had a higher score in terms of environmental sensitivity.
\end{abstract}

Keywords: environmental awareness, environmental sensitivity, classroom, religious culture and ethics, teacher candidates

\section{Introduction}

When a human life begins, an undeniable mutual relationship between the environment and the individual also begins. This relationship of human beings with the environment brings the task of leaving the environment clean and sustainable to the next generation as well. Growing environmentally friendly people seems to be a debt to future generations(Karataş, 2014). The environment is the ambiance where living and non-living factors exist in a certain harmony and unity together(Erten, 2000). It is our duty to protect all the living and non living. Whilst the State should take responsibility for educating teachers who are more sentitive to the environment (Erten, 2000). Society can be more conscious by educating more sensitive teacher candidates to vital environmental problems such as climate change, global warming, extinction of species, melting of glaciers, ozone layer perforation. In fact, protecting the world is the common duty of all teachers on earth. Because this makes the Earth sacred and vital to create a balance between human activities and ensuring the protection of the Earth's resources and conditions that sustain life (Erhabor, 2018).

Individuals are obliged to carry out activities that affect the environment every day and they are affected by the environment equally. This mutual interaction reveals the necessity of individuals to understand the environment well (Chepesiuk, 2007). In addition, developing technology and increasing population demands vast energy sources for consuming (Chaar \& Lamont, 2010). Radical social changes and the rapid growth of the technology charge the society to be conscious of the environment.

Individuals' behavior towards the environment is a reflection of their environmental sensitivity (Gadenne, Kennedy $\&$ McKeiver, 2009). Environmental sensitivity can only be achieved through effective and conscious environmental education, and children's pro-social behavior should also be influenced through observations, experiences, and education, both at home and at school (Musser and Diamond, 1999).

Informative activities for environmental awareness is usually carried out in schools and public institutions. It is included in the course syllabi in almost every semester that we need to protect the environment. Nowadays, young people have an intense interest in the promotion of environmentally friendly practices, and it can be said that children's awareness of environmental concerns has also increased (Musser and Diamond, 1999). 
The attitudes, values and skills that are aimed to be developed with environmental education have become one of the most important outputs which should be brought to the individuals by the education systems. Environmental education should start at a very early age. Environmental education is efficient in preschool education in natural environments when it is given by qualified and conscious teachers (Karataş \& Aslan, 2012).

Adopting permanent and sustainable approaches to solve environmental problems in the short and long term is only possible by training young people(Yalçın \& Demir, 2013). This can only be achieved by continuing the environmental training activities. Prospective teachers are obliged to raise awareness about the environment and create behavior changes by gaining positive attitudes in their students.

Bradley et al. (2010) stated that in a study conducted abroad, participants' environmental knowledge was increased by $22 \%$ and their attitudes towards the environment changed positively. Environmental awareness, which can also be defined as the transfer of natural and environmental heritage to the next generation, should be established in all segments of the society.

In addition to preserving the natural, cultural and aesthetic environment, environmental education should include a process that extends from preschool to elementary school and university (Yalçın, \& Demir, 2013). It is necessary to provide children with the environmental awareness from a holistic perspective.

Among the teachers that the child encounters at an early age, there is a kindergarten and then a Primary school class teacher. Primary school teachers achieve their objectives in some of their courses, like environmental education in life sciences courses. As a role model, the place of the primary school teacher is important as the place of the Religious Culture and Ethics teacher in creating environmental (Aktepe \& Girgin, 2009).

All sacred religions give particular importance to directing their views of the natural environment and regulating their relationship with the environment. The holy books tell us that nature was created by God. It is true that the earth is a legacy to the next generation. Not every country makes as much effort as it should for this matter. The global community is concerned about existing environmental pollution and degradation (Amandeep Kaur. Chahal, 2018). As environmental problems increase, research meetings should be held by developed countries more. Environmental problems, which have great importance in recent years, are caused by unpredictable climatic conditions, floods, increase in average global temperature, depletion of the ozone layer, urban degradation and drought (Erhabor, 2018). Teachers' views and approaches to these problems are also very important, because the teachers will shape the whole society by educating children on the subject of environmental awareness.

Social media, is gaining importance in increasing environmental concerns and environmentally responsible behaviors in society (Krätzig \& Warren-Kretzschmar, 2014). In particular, as the social media usage of young people increases, information on environmental problems is easily shared. In groups and forums, members of environmental organizations (such as Greenpeace, the European Environment Agency, the United Nations Environment Program) carry out conversations and discussions about environmental pollution, ozone layer depletion and water pollution.

Teacher candidates are responsible for promoting environmental awareness in their schools. In some European Union country programs like Belgium, Finland and Greece environmental education is given as a separate course, in Austria and Denmark this course is given by interdisciplinary understanding and in other countries like Netherlands and UK environmental education is intertwined with different courses (Tanriverdi, 2009).

Environmental education is an interdisciplinary field of study and should be conducted with an interdisciplinary approach (Unesco, 2019). Since environmental problems are also the issues society faces in daily life, environmental education should be provided with an interdisciplinary approach. For this reason, interdisciplinary approach are needed as the gains in environmental awareness in social life and the gains in religious culture and ethics courses are very important.

Tanriverdi (2009) analyzed new Turkish primary school curriculum in terms of sustainable environmental education. She found that learning outcomes about renewable energy sources were only in science lessons and were in a small scale. In the framework of formal education in Turkey, although there is no specific curriculum for environmental education, basic training for the environment is included in different courses of primary and secondary education programs (Uzun, 2007). There is no standard education in the faculties of education or theology faculties in higher education. However, there are environmental education courses in the Faculty of Education in Classroom Teaching and Science Teaching. It is aimed to educate individuals who are more sensitive to the environment in the teaching of religion, which exists both in classroom teaching and in the teaching of Religious Culture and Ethics programs.

For this reason, both Environmental and Environmental Awareness of Teacher Candidates of Faculty of Theology 
(Religious Culture and Ethics) and Primary School Teaching Department were examined in terms of some variables. In these two departments, there are religious lessons and it can be checked whether religion has an effect on creating environmental awareness of the students. Loving and protecting the nature, which is one of the basic functions of education, imposes responsibility on every individual. The purposes of religion can be used to give this responsibility.

\section{Methodology}

\subsection{Problem Statement}

The problem statement of this research, which was conducted in order to measure the environmental sensitivity of the candidates from two different teacher programs, constitutes the problem status. For this,

Do the teacher candidates' attitudes towards environmental problems change in the Faculty of Theology (Religious Culture and Ethics) and the Faculty of Education (Classroom Teaching)?

1. Do teacher candidates' environmental behaviors change according to the departments?

2. Do teacher candidates' environmental behaviors change according to gender?

\subsection{Participants}

The participants of the study are Nevşehir Hacı Bektaş Veli University Theology Faculty 3rd and 4th grade students (204) and Education Faculty 3rd and 4th grade students (73). Participants were selected as volunteers on a voluntary basis. Participants are teacher candidates who were trained in the teaching of Religious Culture and Ethics. In these two groups of teacher training programs, environmental education is mentioned in ethics and values education. University students' were told that there was a research on environmental education and those who wanted to participate in this research were informed about the survey. The present study focuses on environmental education and on teachers candidates in primary education school in Turkey. Participants are prospective teachers in primary schools.

\subsection{Method}

Relational screening model (Büyüköztürk and ohers, 2010). was used to explain the change of Environmental Awareness and Environmental Sensitivity by branch and gender. The criterion sample design was used in the sample selection. Teacher candidates from two different branches who took Religious Culture and Ethics Teaching course in the undergraduate programs participated in the study.

\subsection{Data Collection Tool and Data Collection}

The "Environmental Awareness and Environmental Sensitivity "scale developed by Timur and Y1lmaz (2013) for prospective teachers was used as data collection tool. The enviromental behaviour scale was developed by Goldman, Yavetz ve Pe'er (2006) and was adapted to the Turkish language and its validity and reliability studies of the scale were conduted by Timur ve Yilmaz. The first dimension of the scale is person's economic benefit of resource conservation activities, the second dimension is environmentally-conscious consumers, the third dimension is nature and leisure activities related to the fourth dimension which is recycling efforts, the fifth dimension is responsible citizenship and the sixth dimension is environmental activism. Scale consists of 20 items.

Environmental Awareness and Environmental Sensitivity' scale is a 5 likert type scale which consist of twenty items. The necessary permissions were obtained and the scale were distributed and applied to the teacher candidates. The scale was distributed to 277 teacher candidates on a voluntary basis during the data collection process. 15 minutes were allowed to complete the survey. The data were collected in 2018-2019 fall semester. At the end of factor analysis applied on obtained data, it has been found out that the scale has six dimensions. The Cronbach's Alpha reliability coefficient of the five-point Likert-type "Environmental Behavior Scale", which consisted of 20 items, was calculated as 0.91 . For example, the first item is "I warn people who throw garbage in public areas or harm the environment".

\subsection{Analysis and Interpretation of the Data}

The data were entered into SPSS program, were analyzed with SPSS 22 package program. Descriptive statistical techniques (median, arithmetic mean, standard deviation) were used to determine the general distributions of the teacher candidates' responses to the applied scale and to investigate whether the quantitative data showed normal distribution. One Way Analysis of Variance (ANOVA) was used to analyze the data, especially to find out the difference between male and female students. Frequency and percentage distributions were sometimes used in data analysis. 


\section{Results}

In this section, the results of the findings, which were obtained as a result of statistical analysis of the data collected for the solution of the problem discussed in the study, are given. As a result of the study, it was determined that there was no significant difference between the branches and genders of Environmental Awareness and Environmental Sensitivities of teacher candidates. However, a significant difference was found between the sections in the Environmental Sensitivity dimension of the scale.

\subsection{Finding: Do Environmental Behaviors of Teacher Candidates Change According to Departments?}

\section{Environmental Behaviors According to the Departments}

Teacher candidates' environmental behaviors vary according to the departments they belong to. It is seen that Teacher candidates of Faculty of Theology who say "I reuse nylon bags that were used as shopping bags.' have the highest frequency. For both departments, "I send mails about environmental issues to the media." has the lowest frequency. "I save energy by turning off unused electrical devices and lights." and "I save water at home. (I turn off the tap when brushing my teeth or washing dishes.)" have high frequency in both departments. When it comes to saving money, prospective teachers can be said to be more careful. It can be also said that teacher candidates are not very sensitive about taking back returnable bottles and participating in campaigns to protect and clean public places.

\section{Environmental Behaviors According to the Departments}

The teacher candidates' environmental sensitivities are best described with the statement "I notice bird sounds, animals and flowers when I'm out." Teacher candidates are not sensitive to prevention of environmental pollution, reading articles on environmental issues in newspapers and magazines or watching television programs on environmental and nature issues at all. Hiking and excursions are the activities which are mostly preferred by Religious Culture and Ethics teacher candidates. It can be said that there is more communication with God (Allah) in nature or that watching nature reminds God (Allah) more of them. It can be said that the students of the faculty of education are mostly involved in campaigns to prevent environmental pollution. It can be said that both program students are careful to leave the devices like theair conditioner on when leaving the room.

\subsection{Findings: According to Gender}

Do Teacher Candidates' Environmental Behaviors Change According to Gender?

\section{Environmental Behaviors According to Genders}

The teacher candidates' environmental behaviors change according to their genders. Women can be said to be more sensitive about reporting environmental issues to the authorities, buying eco-friendly products, reusing nylon bags previously used as shopping bags, taking waste to recycling points such as newspapers and plastic bottles, than men. Men are more sentive about saving water at home (I turn off the tap when brushing my teeth or washing dishes), saving energy by turning off unused electrical devices and lights, taking back returnable bottles, and participating in campaigns to protect and clean public places.

\section{Environmental Behaviors According to Genders}

According to the data acquired from Table $3 \mathrm{~B}$, it is seen that women are more sensitive to the environment when it comes to warning people throwing garbage in public spaces or damaging the environment, collecting and throwing trash that people throw in public places, throwing trash in public places and throwing trash in public places, taking part in campaigns organized to prevent environmental pollution and going trekking and hiking. Developing a sensitivity of recognizing birds' voices, animals and flowers while outdoors is a very important for both genders and it also has the highest frequency. It can be said that women are more active than men in taking part in campaigns and environmental organizations to prevent environmental pollution. It is seen that men watch television programs about environment and nature more.

\section{Discussion}

Environmental problems have started to take place in our lives more with globalization and these problems have led us to the search for solutions. Human attitude and sensitivity towards the environment has become more questionable. It has great importance for our future that teachers who are the inevitable parts of the solution should teach their students how to be enviromentally friendly.

In this study, it was determined that the attitudes of teacher candidates towards environmental problems were moderate and positive. The findings coincide with those of Kahyaoğlu \& Özgen (2011). It was also observed that theology students were more sensitive to nature thanks to the education they received from religious sources. It is seen that education students are better at promoting awareness about environmental protection. Theology students 
were found to be more sensitive about wasting than others.

The data reported that female students are more sensitive to environmental problems. In another study, Erol and Gezer (2006) stated that girls' attitudes towards the environment were higher than that of boys. Again in the study conducted by Deniş and Genç (2007), it was stated that girls' attitudes towards the environment were higher than that of boys. Various researchers have reported that there is a meaningful relation between gender and environmental thoughts and behaviors (Bjerke et al, 2006 and Tuncer et al, 2005).

Instead of dealing with environmental problems through the media, students prefer protecting nature itself. Students are conscious enough about energy and water saving. It can be said that students are more sensitive when it comes to saving money. The students should be directed to joint activities on cleaning the environment. In addition, prospective teachers should be encouraged to read and research more on environmental awareness and environmental sensitivity.

It is necessary to encourage teacher candidates to take positive initiatives in solving environmental problems. Because when they become teachers, they need to be sensitive in order to train sensitive students. In order to be sensitive to the environmental problems that arise with the rapid development of technology in the world, it is necessary to take initiatives within the country and to carry out joint projects with other countries. In order to protect the environment and prevent environmental problems, individuals may need help developing attitude towards environment and environmental problems (teacher candidates should be exemplary). Students should participate in scientific studies such as seminars, panels and conferences on the environment, and it may be beneficial for them to take different initiatives on their own.

The courses related to the environment and environmental problems should be added to the programs of the Faculties of Theology and the Faculties of Education. Because higher education institutions are responsible for training individuals who have the necessary knowledge, skills and values to contribute to the improvement of the quality of life of the global community (Corcoran, 2004). The television can be used as a mass communication tool to promote environmental awareness among male students, and female students can be encouraged to take park in campaigns.

\section{Conclusion}

It is not possible to say that basic knowledge always helps developing environmental sensitivity and behavioral behaviors of students (Schmidt 2007), so environmental sensitivity can be created by performing different activities and projects occasionally. It is necessary to question the effectiveness of the courses given on environmental issues, and then to analyze the educational needs and develop a new program suitable for all levels in schools. Therefore, increasing environmental knowledge will enable us to educate more conscious and sensitive individuals in society. Behaviors of the educators and teacher candidates who have a very important role in training future generations should be continually studied.

Turkey is a developing country with its young productive population and its educational system is developing rapidly. Consequently, as being as the young must be integrated to the educational system, school curricula are changing accordingly. Meanwhile, teacher program curriculum could be renewed in a way that concepts about environment are thought with the help of context-based approaches. Much more learning outcomes related to environmental sensitivity must be added to the primary school teachers and Religious Culture and Ethics teachers curricula if we want that the future generation solve environmental problems in daily life context.

\section{References}

Aktepe, S. \& Girgin, S. (2009). İlköğretimde eko-okullar ve klasik okulların çevre eğitimi açısından karşılaştırılması. Illköğretim Online, 8(2), 401-414.

Bradley, J.C., T. M. Waliczek \& J. M. Zajicek (2010). Relationship Between Environmental Knowledge and Environmental Attitude of High School Students, The Journal of Environmental Education, 30(3), 17-21. https://doi.org/10.1080/00958969909601873.

Büyüköztürk, Ş., Kılıç-Çakmak, E., Akgün, Ö. E., Karadeniz, Ş. \& Demirel, F. (2010). Bilimsel araştırma yöntemleri (6. bs.). Ankara: Pegem Akademi.

Chaar, L. E. \& Lamont, L. A. (2010). Nourishing green minds in the land of oil. Renewable Energy, 35, 570-575. https://doi.org/10.1016/j.renene.2009.08.015.

Chepesiuk, R. (2007). Environmental literacy: Knowledge for a healthier public. Environmental Health Perspectives, 115(10), 494-499. https://www.ncbi.nlm.nih.gov/pmc/articles/PMC2022675/ adresinden erişilmiştir. https://doi.org/10.1289/ehp.115-a494. 
Corcoran, P.B. \& Wals, A.E.J. (2004). The problematics of sustainability in higher education: an introduction. Higher Education and The Challenge of Sustainability: Problematics, Promise and Practice (Eds: Corcoran, P.B. and Wals, A.E.J.). Kluwer Academic Publishers. SBN 978-0-306-48515-2.

Erhabor, N. I. (2018). Developing Leaders Through Mentoring in Environmental Education. Electronic Green Journal, 1(41), 2-10. Retrieved from http://search.ebscohost.com/login.aspx?direct=true\&site=eds-live\&db=eih\&AN=129777034.

Erten, S. (2000). Empirische Untersuchungen zu Bedingungen der Umwelterziehung-ein interkulturellervergleich auf der Grundlage der Theorie des geplanten Verhaltens. Tectum Verlag. Marburg.

Felice, J., Giordan, A. \& Souchon, C. (1985). Interdisciplinary Approaches in Environmental Education. Unesco-UNEP International Environmental Education Programme, Environmental Education Series (14). http://unesdoc.unesco.org/images/0006/000633/063334eo.pdf.

Gadenne, D.L, Kennedy, J. \& McKeiver, C. (2009). An Empirical Study of Environmental Awareness and Practices in SMEs January, Journal of Business Ethics, 84(1), 45-63, https://doi.org/10.1007/s10551-008-9672-9.

Goldman, D., Yavetz, B. \& Pe'er, S. (2006). Environmental literacy in teacher training in Israel: Environmental behavior of new students. Journal of Environmental Education, 38(1), 3-22. https://doi.org/10.3200/JOEE.38.1.3-22.

Karataş, A. \& Aslan, G. (2012). İlköğretim Öğrencilerine Çevre Bilincinin Kazandırılmasında Çevre Eğitiminin Rolü: Ekoloji Temelli Yaz Kampı Projesi Örneği, Journal of World of Turks, 4(2).

Karataş, A. (2014). Çevre Sorunlarına Alternatif Bir Çözüm Aracı Olarak Yükseköğretimde Çevre Eğitimi Niğde Üniversitesi, The Second Symposium on Environment Morality, Proceedings Books, Adıyaman, Turkey.

Kaur A.\& H. S. Chahal, H.S. (2018). Role of Social Media in increasing Environmental issue Awareness. Publication:Researchers World, 9(1). https://doi.org/10.18843/rwjasc/v9i1/03.

Krätzig \& Warren-Kretzschmar.(2014). Using Interactive Web Tools in Environmental Planning to Improve Communication about Sustainable Development, Sustainability, 2014, 6(1), 236-250; https://doi.org/10.3390/su6010236.

MEB. ( 2014). Okul Öncesi, İlköğretim ve Ortaöğretim Programları. http://tegm.meb.gov.tr.

Musser, L. M. \& Diamond, E. K. (2010). The Children's Attitudes Toward the Environment Scale for Preschool Children. The Children's Attitudes Toward the Environment Scale for Preschool Children, the Journal of Environmental Education Journal, 30(2), 23-30 | Published online: 31 Mar 2010, https://doi.org/10.1080/00958969909601867.

Schmidt, J.E. (2007). From intentions to actions: The role of environmental awareness on college students. www.uwlax.edu/urc/JUR-online/PDF/2007/schmidt.pdf.

T. Bjerke, C. Thrane \& J. Kleiven. (2006). Outdoor recreation interests and environmental attitudes in norway, Managing Leisure, 11, 116-128. https://doi.org/10.1080/13606710500520197.

Tanrıverdi, B. (2009). Sürdürülebilir çevre eğitimi açısından ilköğretim programlarının değerlendirilmesi. Eğitim ve Bilim, 34(151).

Timur, S \& Yılmaz, M. (2013). Çevre Davranış Ölçeğinin Türkçe'ye Uyarlanması, Adaptation of Environmental Behavior Scale to Turkish, GEFAD /GUJGEF 33(2), 317-333.

Tuncer, G, Ertepınar, H., Tekkaya, C. \& Sungur, S. (2005). Environmental attitudes of young people in Turkey: Effects ofschool type and gender, Environmental Education Research, 11(2), 215-233. https://doi.org/10.1080/1350462042000338379.

UNESCO, Interdisciplinary Approaches in Environmental Education. Unesco UNEP International Environmental Education Programme, Environmental Education Series (14). Erişim:04.04.2019, http://unesdoc.unesco.org/images/0006/000633/063334eo.pdf .

Uzun, N. (2007). Ortaöğretim Öğrencilerinin Çevreye Yönelik Bilgi ve Tutumları Üzerine Bir Çalışma. Yayınlanmamış Doktora Tezi. Hacettepe Üniversitesi, Fen Bilimleri Enstitüsü, Ankara.

Yalçın, H. \& Demir, E. (2013). Türkiye'de doğal malzemeler, çevre, sağlık ve eğitim arasındaki ilişkiler. Uluslararası Çevresel Etki Değerlendirmesi Kongresi, İstanbul Kültür Merkezi, İstanbul, 08-10 Kasım, Bildiri Kitab1, 173-178. 